\title{
Pengaruh Kemiringan Posisi Modul Surya Prototipe 200 Wp Dengan Tracking Sistem Terhadap Energi Listrik Yang Dihasilkan
}

\author{
Syarif Hidayat ${ }^{1}$; Agung Hariyanto ${ }^{2}$; Ridha Yasser $^{3}$ \\ ${ }^{1,2,3}$ Teknik Elektro, Sekolah Tinggi Teknik PLN \\ ${ }^{1}$ syarifhidayat@sttpln.ac.id
}

\begin{abstract}
The use of solar modules in converting solar energy into electrical energy is something interesting to study. In this case the $200 \mathrm{WP}$ solar module is used as an experiment to see the symptoms produced during a certain time. The material of the solar module is silicon oxide crystal (SiO2). The process of converting solar energy into electricity can be affected by the angle between the rays that come with the solar module field. If the position of the solar module does not change throughout the day, this angle depends on the position of the sun or time. In this case, it is necessary to study how the angle that produces the most electricity is adjusted to the change in time in one day. The energy produced by solar tracking systems is more optimal than that of solar modules in an immovable state. Changes in the position of the solar module should be done once every half hour with a slope angle of $+5^{0}$ from the initial position of the clock change. At the position of the solar module is not moving, the maximum power is at 12:30 a.m. which is 5.129 watts.
\end{abstract}

Keywords: Solar energy conversion, the slope of a solar module, solar tracking system.

\begin{abstract}
ABSTRAK
Penggunaan modul surya dalam mengubah energi matahari menjadi energi listrik merupakan sesuatu yang menarik untuk diteliti. Dalam hal ini digunakan modul surya 200 WP sebagai percobaan untuk melihat gejala-gejala yang dihasilkan selama satu waktu tertentu. Bahan dari modul surya adalah kristal silicon oksida (SiO2). Proses konversi energi matahari menjadi listrik ini dapat dipengaruhi sudut antara sinar yang datang dengan bidang modul surya. Apabila posisi modul surya tidak berubah sepanjang hari maka sudut ini tergantung pada posisi matahari atau waktu. Dalam hal ini perlu pengkajian bagaimana sudut yang paling banyak menghasilkan energi listrik disesuaikan dengan perubahan waktu dalam satu hari. Energi yang dihasilkan oleh solar tracking sistem lebih optimal dibandingkan dengan modul surya dalam keadaan tidak bergerak. Perubahan posisi modul surya dilakukan sebaiknya setengah jam sekali dengan sudut kemiringan $+5^{0}$ dari posisi awal perubahan jam. Pada posisi modul surya tidak bergerak, daya maksimum terdapat pada jam 12.30 wib yaitu sebesar 5,129 watt.
\end{abstract}

Kata kunci: Konversi energi matahari, kemiringan modul surya, solar tracking system. 


\section{PENDAHULUAN}

Pemanfaatan sinar matahari untuk diubah langsung / konversi langsung menjadi energi listrik dengan menggunakan modul surya memilki kecenderungan yang semakin baik dalam hal penggunaannya, perubahan posisi matahari terhadap modul surya terus berubah sepanjang hari. Bahkan dalam satu tahun juga posisi nya berubah terhadap khatulistiwa. Dengan menggunakan alat yang bisa mengubah posisi modul surya terhadap arah datangnya cahaya matahari, maka akan dilakukan perubahan / penelitian posisi sudut seperti bagaimana yang paling banyak menghasilkan energi listrik.

\section{METODE/PERANCANGAN PENELITIAN}

\subsection{Sistem Kerja Diagram Prototipe PLTS}

Blok diagram rangkaian memerlukan salah satu bagian yang terpenting dalam perancangan suatu alat, karena blok diagram rangkaian inilah dapat diketahui cara kerja rangkaian keseluruhan. Sehingga keseluruhan blok diagram rangkaian tersebut akan menghasilkan suatu sistem yang dapat difungsikan atau dapat bekerja sesuai perencangan. Sistem kerja PLTS di terdiri dari panel surya, solar charge controller, baterai dan inverter. Adapun skema sistem PLTS di Tangerang tersebut sebagai berikut:

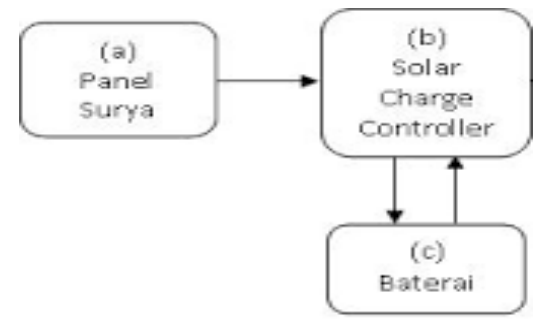

Gambar 1. Blok diagram PLTS menggunakan modul surya

\subsection{Komponen Prototipe PLTS}

\subsubsection{Modul Surya}

Panel surya yang digunakan mempunyai rating daya $200 \mathrm{Wp}$. Besar rating berbeda disebabkan karena karakteristik modul surya jenis P-N dan juga dipengaruhi oleh jumlah sel terhadap luas dari modul tersebut.

\subsubsection{Solar Charge Controller}

Solar charge controller yang digunakan adalah sebanyak 1 buah dengan Sseries Sc 991.

\subsubsection{Baterai}

Baterai bank yang menggunakan sistem tegangan $12 \mathrm{~V}$. Terdiri dari 1 buah baterai dengan kapasitas 3,5 Ah.

\subsection{Alat Ukur}

\subsubsection{Avometer}

Avometer berasal dari kata "AVO" dan "meter". 'A' artinya ampere, untuk mengukur arus listrik. ' $\mathrm{V}$ ' artinya voltase, untuk mengukur voltase atau tegangan. ' $\mathrm{O}$ ' artinya ohm, untuk mengukur ohm atau hambatan. Terakhir, yaitu meter atau satuan dari ukuran. AVO Meter sering disebut dengan Multimeter atau Multitester. Secara umum, pengertian dari AVO meter adalah suatu alat untuk mengukur arus, tegangan, baik tegangan bolak-balik (AC) maupun tegangan searah (DC) dan hambatan listrik. Alat ini didalam memperlihatkan hasil pengukurannya menggunakan format digital. 


\section{KILAT}

Vol. 8, No. 2, Oktober 2019, P-ISSN 2089-1245, E-ISSN 2655-4925

\subsubsection{Busur Derajat}

Busur derajat adalah peralatan yang digunakan untuk mengukur dan menggambar sudut. Alat ini biasanya berbentuk setengah lingkaran, walau ada juga yang berupa lingkaran penuh dengan sudut 360 derajat.

\section{HASIL DAN PEMBAHASAN}

\subsection{Pelaksanaan Penelitian}

Kota Tangerang adalah sebuah daerah yang terletak di Provinsi Banten. PLTS ini hanya sebuah prototipe dengan 1 buah panel $200 \mathrm{Wp}$. Setelah memperoleh hasil pengukuran dan perhitungan, maka akan diperoleh data-data dari hasil pengukuran.

\subsection{Hasil Penelitian}

Adapun hasil tersebut sebagaimana tertuang pada tabel dengan dilengkapi dengan grafik dari hasil perolehan tabel yang ada. Untuk mengetahui nilai yang ada dengan menggunakan avo meter.

3.2.1. Hasil Pengukuran Modul Surya pada Keadaan Miring $1^{0}$ Menghadap Utara (Panel dengan keadaan diam)

Langkah yang harus dilakukan sebelumnya melakukan dimensi solar cell. Data spesifik dari solar cell adalah:

Solar module:

\section{Spesifikasi}

Max. Power (Pmax)

Max. Power Voltage (Vmp)

Max. Power Current (Imp)

Open Circuit Voltage (Voc)

Short Circuit Current (Isc)

Nominal Operating Cell Temp (NOCT)

Max. System Voltage

Max. Series Fuse

Weight

Module Efficiency

Dimension

\section{Keterangan}

$200 \mathrm{~W}$

$26,5 \mathrm{~V}$

$7,55 \mathrm{~A}$

$32.8 \mathrm{~V}$

$8,05 \mathrm{~A}$

$-40^{\circ} \mathrm{C} \pm 85^{\circ} \mathrm{C}$

$1000 \mathrm{Vdc}$

$16 \mathrm{~A}$

$50 \mathrm{~kg}$

$13,7 \%$

$1480 \times 982 \times 35 \mathrm{~mm}$ 
Tabel 1. Data pada keadaan modul surya tetap

\begin{tabular}{|c|c|c|c|}
\hline Jam & $\begin{array}{c}\text { Tegangan } \\
\text { (Vpv) }\end{array}$ & $\begin{array}{c}\text { Arus } \\
\text { (Ivp) }\end{array}$ & $\begin{array}{c}\text { Daya } \\
\text { (Ppv) }\end{array}$ \\
\hline $8: 00$ & 31.775 & 0.1434 & 4.557 \\
\hline $8: 30$ & 32.214 & 0.1502 & 4.84 \\
\hline $9: 00$ & 31.775 & 0.1434 & 4.557 \\
\hline $9: 30$ & 31.043 & 0.1434 & 4.452 \\
\hline $10: 00$ & 30.75 & 0.1502 & 4.62 \\
\hline $10: 30$ & 32.214 & 0.1571 & 5.06 \\
\hline $11: 00$ & 32.214 & 0.1571 & 5.06 \\
\hline $11: 30$ & 32.214 & 0.1502 & 4.84 \\
\hline $12: 00$ & 32.068 & 0.1571 & 5.037 \\
\hline $12: 30$ & 32.654 & 0.1571 & 5.129 \\
\hline $13: 00$ & 32.507 & 0.1502 & 4.884 \\
\hline $13: 30$ & 32.946 & 0.1502 & 4.95 \\
\hline $14: 00$ & 31.336 & 0.1434 & 4.494 \\
\hline $14: 30$ & 29.139 & 0.1366 & 3.98 \\
\hline $15: 00$ & 28.554 & 0.1366 & 3.9 \\
\hline Rata2 & 31.56 & 0.1484 & 4.690667 \\
\hline
\end{tabular}

Perhitungan energi panel sel surya (Epv) posisi diam $10^{\circ}$ kearah utara: Epv $\quad=$ Ppv $\times$ Waktu $=4.690667$ Watt $\times 8$ jam $=37.52533 \mathrm{Wh}$

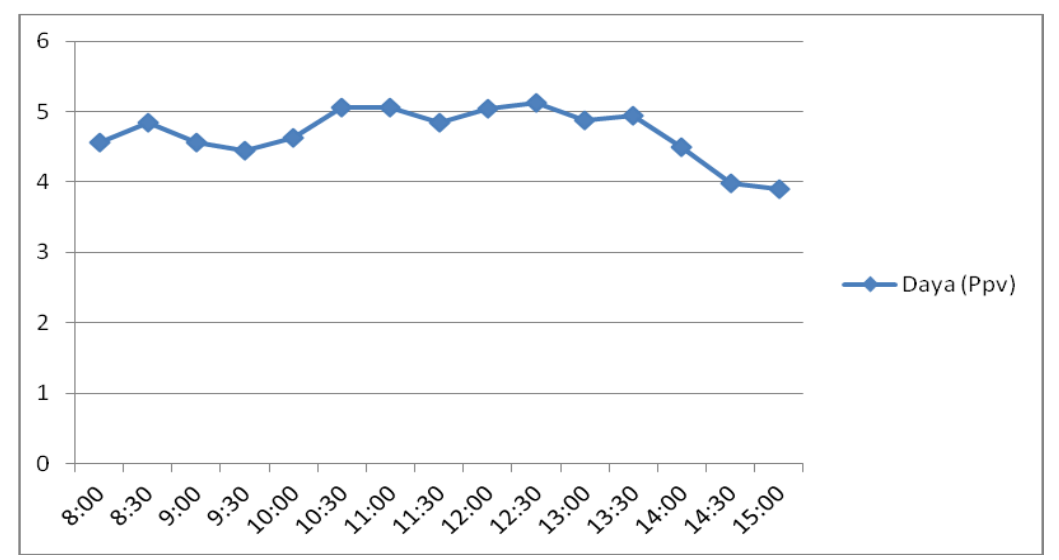

Gambar 2. Grafik Daya Modul Sell Surya Diam dengan waktu

Berdasarkan Gambar 2 terlihat bahwa jam 12.30 adalah yang menghasilkan daya yang paling besar. Dimana pada posisi panel ini yang paling tegak lurus berada pada jam 12:00. 


\section{KILAT}

Vol. 8, No. 2, Oktober 2019, P-ISSN 2089-1245, E-ISSN 2655-4925

\subsubsection{Hasil Perhitungan Modul Surya dengan Keadaan Dinamis}

\section{a. Percobaan 1}

Perhitungan data dalam hal ini dilakukan dengan merotasikan modul surya tiap satu jam nya sebesar $15^{\circ}$ timur ke bagian barat menggunakan solar tracking system, rotasi tersebut dilakukan sama dengan modul tetap $10^{\circ}$ menghadap arah utara. Penelitian ini dilakukan tetap pada pukul 08.00 wib hingga pukul $15.00 \mathrm{wib}$.

Tabel 2. Data modul surya dengan solar tracking system per jam

\begin{tabular}{|c|c|c|c|c|}
\hline Jam & $\begin{array}{c}\text { Posisi } \\
\left({ }^{0}\right)\end{array}$ & $\begin{array}{c}\text { Tegangan } \\
\text { (Vpv) }\end{array}$ & $\begin{array}{c}\text { Arus } \\
\text { (Ipv) }\end{array}$ & Daya $)$ \\
\hline $8: 00$ & -60 & 32.36071 & 0.157073 & 5.083 \\
\hline $9: 00$ & -45 & 32.21429 & 0.143415 & 4.62 \\
\hline $10: 00$ & -30 & 30.75 & 0.150244 & 4.62 \\
\hline $11: 00$ & -15 & 32.65357 & 0.143415 & 4.683 \\
\hline $12: 00$ & 0 & 32.65357 & 0.157073 & 5.129 \\
\hline $13: 00$ & 15 & 32.36071 & 0.157073 & 5.083 \\
\hline $14: 00$ & 30 & 32.50714 & 0.157073 & 5.106 \\
\hline $15: 00$ & 45 & 29.87143 & 0.143415 & 4.284 \\
\hline Rata2 & & 31.92143 & 0.151098 & 4.826 \\
\hline
\end{tabular}

Perhitungan energi panel sel surya (Epv) posisi berotasi:

Epv $=$ Ppv $\mathrm{x}$ Waktu $=4.826 \mathrm{Watt} \times 8 \mathrm{Jam}=38.608 \mathrm{Wh}$

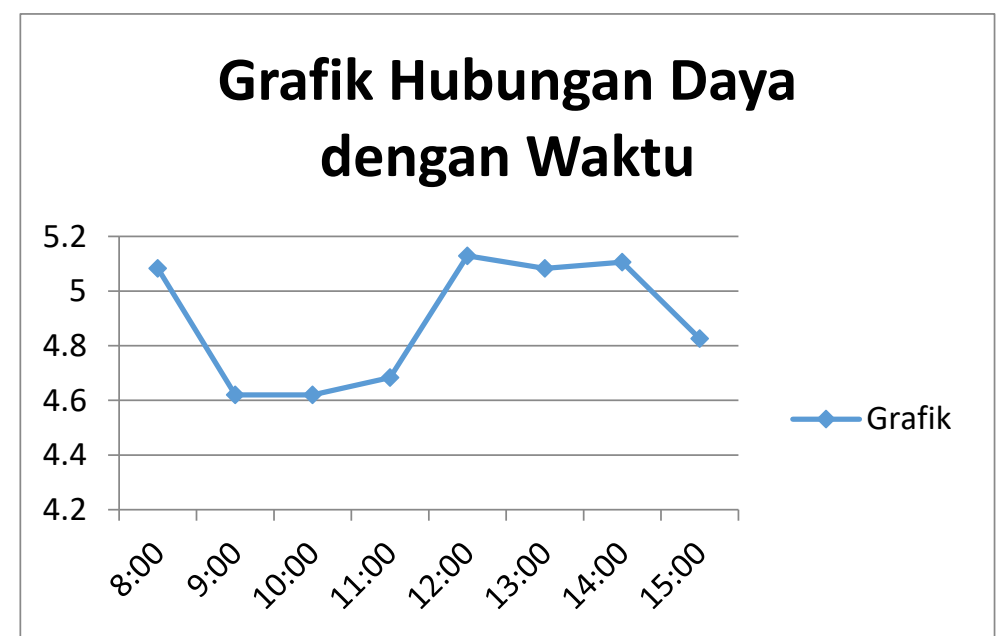

Gambar 3. Grafik hubungan daya dengan waktu per jam dengan pergeseran $15^{0}$ 
Pada Gambar 3 terlihat bahwa daya maksimal didapat pada jam 12:00, namun daya yang di dapat pada jam 8:00 hampir menyerupai daya pada jam 12:00. Hal ini disebabkan pada jam 8:00 cuaca cukup cerah, dan pada jam selanjutnya intensitas cahaya matahari berkurang dengan keadaan cuaca berawan.

\section{b. Percobaan 2}

Perhitungan data dalam hal ini dilakukan dengan merotasikan modul surya setiap setengah jamnya sebesar $7,5^{\circ}$ timur ke bagian barat menggunakan solar tracking system, rotasi tersebut dilakukan sama dengan modul tetap $10^{\circ}$ menghadap arah utara. Penelitian ini dilakukan tetap pada pukul 08.00 wib hingga pukul 15.00 wib.

Tabel 3. Data modul surya dengan solar tracking system per setengah jam

\begin{tabular}{|c|c|c|c|c|}
\hline Jam & $\begin{array}{c}\text { Posisi } \\
(\end{array}$ & Vpv & Ipv & Ppv \\
\hline $8: 00$ & -60 & 32.36071 & 0.157073 & 5.083 \\
\hline $8: 30$ & -52.5 & 32.94643 & 0.150244 & 4.95 \\
\hline $9: 00$ & -45 & 32.21429 & 0.143415 & 4.62 \\
\hline $9: 30$ & -37.5 & 30.89643 & 0.143415 & 4.431 \\
\hline $10: 00$ & -30 & 30.75 & 0.150244 & 4.62 \\
\hline $10: 30$ & -22.5 & 33.67857 & 0.170732 & 5.75 \\
\hline $11: 00$ & -15 & 32.65357 & 0.143415 & 4.683 \\
\hline $11: 30$ & -7.5 & 32.21429 & 0.150244 & 4.84 \\
\hline $12: 00$ & 0 & 32.65357 & 0.157073 & 5.129 \\
\hline $12: 30$ & 7.5 & 32.65357 & 0.150244 & 4.906 \\
\hline $13: 00$ & 15 & 32.36071 & 0.157073 & 5.083 \\
\hline $13: 30$ & 22.5 & 31.775 & 0.157073 & 4.991 \\
\hline $14: 00$ & 30 & 32.65357 & 0.157073 & 5.129 \\
\hline $14: 30$ & 37.5 & 30.75 & 0.143415 & 4.41 \\
\hline $15: 00$ & 45 & 29.87143 & 0.143415 & 4.284 \\
\hline Rata2 & & 32.02881 & 0.15161 & 4.8606 \\
\hline
\end{tabular}

Perhitungan energi panel sel surya (Epv) posisi berotasi:

Epv $=$ Ppv x Waktu $=4.8606$ Watt $\times 8$ Jam $=38.8848 \mathrm{Wh}$ 


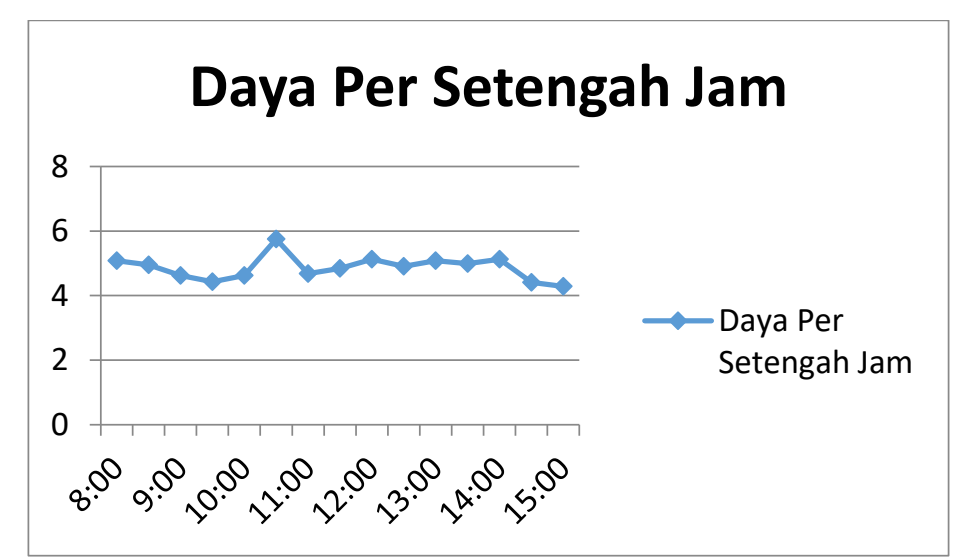

Gambar 4. Grafik hubungan daya dengan waktu per setengah jam dengan pergeseran $7,5^{\circ}$

Pada Gambar 4 terlihat daya maksimum yang dihasilkan modul surya terdapat pada jam 10:30.

c. Percobaan 3

Perhitungan data dalam hal ini dilakukan dengan merotasikan modul surya tiap satu jamnya sebesar $15^{0}+5^{0}$ seiring pergantiaan jam dari timur ke bagian barat menggunakan solar tracking system

Tabel 4. Data modul surya dengan solar tracking system dengan posisi kemiringan panel $+5^{0}$ dari posisi awal per jam

\begin{tabular}{|c|c|c|c|c|}
\hline Jam & Posisi () & Vpv & Ipv & Ppv \\
\hline $8: 00$ & -55 & 32.65357 & 0.150244 & 4.906 \\
\hline $9: 00$ & -40 & 32.21429 & 0.143415 & 4.62 \\
\hline $10: 00$ & -25 & 30.75 & 0.150244 & 4.62 \\
\hline $11: 00$ & -10 & 32.36071 & 0.143415 & 4.641 \\
\hline $12: 00$ & 5 & 32.50714 & 0.157073 & 5.106 \\
\hline $13: 00$ & 20 & 32.36071 & 0.157073 & 5.083 \\
\hline $14: 00$ & 35 & 32.36071 & 0.157073 & 5.083 \\
\hline $15: 00$ & 50 & 31.18929 & 0.143415 & 4.473 \\
\hline Rata-rata & & 32.04955 & 0.150244 & 4.8165 \\
\hline
\end{tabular}

Perhitungan energi panel sel surya (Epv) posisi berotasi:

Epv $=$ Ppv $\times$ Waktu $=4.8165$ Watt $\times 8$ Jam $=38.532 \mathrm{Wh}$ 


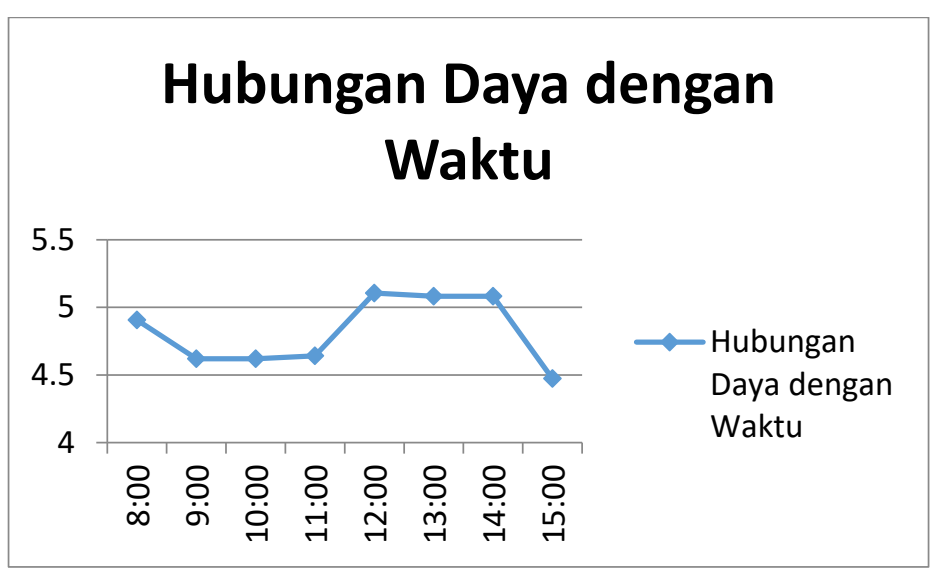

Gambar 5. Grafik modul surya posisi kemiringan panel $+5^{0}$ dari posisi awal per jam dengan waktu

Berdasarkan Gambar 5 terlihat bahwa daya tertinggi didapat pada jam 12:00. Namun daya yang dihasilkan pada percobaan ini kurang efisien pada percobaan 2. Karena daya yang dihasilkan percobaan 2 masih lebih besar dari pada percobaan ke 3

d. Percobaan 4

Perhitungan data dalam hal ini dilakukan dengan merotasikan modul surya tiap setengah jamnya sebesar $7,5^{0}+5^{0}$ seiring pergantiaan jam dari timur ke bagian barat menggunakan solar tracking system, rotasi tersebut dilakukan sama dengan modul tetap $10^{\circ}$ menghadap arah utara. Penelitian ini dilakukan tetap pada pukul 08.00 wib hingga pukul 15.00 wib.

Tabel 5. Data modul surya dengan solar tracking system dengan posisi kemiringan panel $+5^{0}$ dari posisi awal per setengah jam

\begin{tabular}{|c|c|c|c|c|}
\hline Jam & Posisi () & Vvp & Ivp & Ppv5. \\
\hline $8: 00$ & -55 & 32.65357 & 0.150244 & 4.906 \\
\hline $8: 30$ & -47.5 & 32.94643 & 0.150244 & 4.95 \\
\hline $9: 00$ & -40 & 32.21429 & 0.143415 & 4.62 \\
\hline $9: 30$ & -32.5 & 31.18929 & 0.143415 & 4.473 \\
\hline $10: 00$ & -25 & 30.75 & 0.150244 & 4.62 \\
\hline $10: 30$ & -17.5 & 33.67857 & 0.163902 & 5.52 \\
\hline $11: 00$ & -10 & 32.36071 & 0.143415 & 4.641 \\
\hline $11: 30$ & -2.5 & 32.21429 & 0.150244 & 4.84 \\
\hline $12: 00$ & 5 & 32.50714 & 0.157073 & 5.106 \\
\hline $12: 30$ & 12.5 & 32.50714 & 0.150244 & 4.884 \\
\hline $13: 00$ & 20 & 32.36071 & 0.157073 & 5.083 \\
\hline $13: 30$ & 27.5 & 31.62857 & 0.157073 & 4.968 \\
\hline $14: 00$ & 35 & 32.36071 & 0.157073 & 5.083 \\
\hline $14: 30$ & 42.5 & 32.36071 & 0.157073 & 5.083 \\
\hline $15: 00$ & 50 & 31.18929 & 0.143415 & 4.473 \\
\hline Rata rata & & 32.19476 & 0.15161 & 4.883333 \\
\hline
\end{tabular}

Perhitungan energi panel sel surya (Epv) posisi berotasi:

Epv $=$ Ppv $x$ Waktu $=4.883333$ Watt $\times 8$ Jam $=39.06667 \mathrm{Wh}$ 


\section{KILAT}

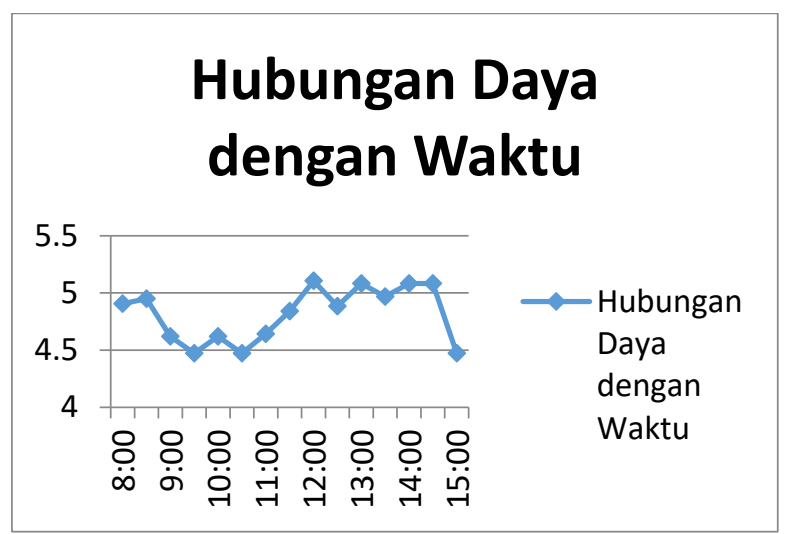

Gambar 6. Grafik modul surya posisi kemiringan panel $+5^{0}$ dari posisi awal per setengah jam dengan waktu

Berdasarkan Gambar 6 terlihat bahwa daya tertinggi didapat pada jam 12:00. Namun daya yang dihasilkan pada percobaan ini lebih efisien dari pada percobaan 3. Karena daya yang dihasilkan percobaan 4 dengan merotasikan setiap setengah jam masih lebih besar dari pada percobaan ke 3 dengan merotasikan setiap satu jam.

e. Percobaan 5

Perhitungan data dalam hal ini dilakukan dengan merotasikan modul surya tiap satu jamnya sebesar $15^{0}-5^{0}$ seiring pergantiaan jam dari timur ke bagian barat menggunakan solar tracking system, rotasi tersebut dilakukan sama dengan modul tetap $10^{\circ}$ menghadap arah utara. Penelitian ini dilakukan tetap pada pukul 08.00 wib hingga pukul 15.00 wib.

Tabel 6. Data modul surya dengan solar tracking system dengan posisi kemiringan panel $-5^{0}$ dari posisi awal per jam

\begin{tabular}{|c|c|c|c|c|}
\hline Jam & Posisi (") & Vvp & Ipv & Ppv \\
\hline $8: 00$ & -65 & 32.50714 & 0.150244 & 4.884 \\
\hline $9: 00$ & -50 & 32.21429 & 0.143415 & 4.62 \\
\hline $10: 00$ & -35 & 30.60357 & 0.150244 & 4.598 \\
\hline $11: 00$ & -20 & 32.50714 & 0.150244 & 4.884 \\
\hline $12: 00$ & -5 & 32.50714 & 0.157073 & 5.106 \\
\hline $13: 00$ & 10 & 32.36071 & 0.157073 & 5.083 \\
\hline $14: 00$ & 25 & 32.94643 & 0.157073 & 5.175 \\
\hline $15: 00$ & 40 & 28.7 & 0.143415 & 4.116 \\
\hline Rata-rata & & 31.7933 & 0.151098 & 4.80825 \\
\hline
\end{tabular}

Perhitungan energi panel sel surya (Epv) posisi berotasi:

Epv $=$ Ppv $\mathrm{x}$ Waktu $=4.80825$ Watt $\times 8$ Jam $=38.466 \mathrm{Wh}$ 


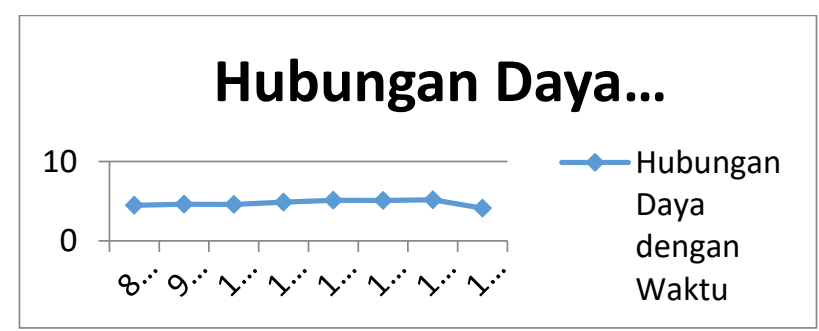

Gambar 7. Grafik modul surya posisi kemiringan panel $-5^{0}$ dari posisi awal per jam dengan waktu

\section{f. Percobaan 6}

Perhitungan data dalam hal ini dilakukan dengan merotasikan modul surya tiap setengah jamnya sebesar $7,5^{0}-5^{0}$ seiring pergantiaan jam dari timur ke bagian barat menggunakan solar tracking system, rotasi tersebut dilakukan sama dengan modul tetap $10^{\circ}$ menghadap arah utara.

Tabel 7. Data modul surya dengan solar tracking system dengan posisi kemiringan panel $-5^{0}$ dari posisi awal per setengah jam

\begin{tabular}{|c|c|c|c|c|}
\hline $\operatorname{Jam}$ & Posisi (") & Vvp & Ipv & Ppv \\
\hline $8: 00$ & -65 & 32.50714 & 0.150244 & 4.884 \\
\hline $8: 30$ & -57.5 & 32.94643 & 0.150244 & 4.95 \\
\hline $9: 00$ & -50 & 32.21429 & 0.143415 & 4.62 \\
\hline $9: 30$ & -42.5 & 31.18929 & 0.143415 & 4.473 \\
\hline $10: 00$ & -35 & 30.60357 & 0.150244 & 4.598 \\
\hline $10: 30$ & -27.5 & 33.67857 & 0.170732 & 5.75 \\
\hline $11: 00$ & -20 & 32.50714 & 0.150244 & 4.884 \\
\hline $11: 30$ & -12.5 & 32.21429 & 0.150244 & 4.84 \\
\hline $12: 00$ & -5 & 32.50714 & 0.157073 & 5.106 \\
\hline $12: 30$ & 2.5 & 32.36071 & 0.157073 & 5.083 \\
\hline $13: 00$ & 10 & 32.36071 & 0.157073 & 5.083 \\
\hline $13: 30$ & 17.5 & 31.62857 & 0.157073 & 4.968 \\
\hline $14: 00$ & 25 & 32.94643 & 0.157073 & 5.175 \\
\hline $14: 30$ & 32.5 & 30.75 & 0.143415 & 4.41 \\
\hline $15: 00$ & 40 & 28.7 & 0.143415 & 4.116 \\
\hline Rata-rata & & 31.94095 & 0.152065 & 4.862667 \\
\hline
\end{tabular}

Perhitungan energi panel sel surya (Epv) posisi berotasi:

Epv $\quad=$ Ppv $\times$ Waktu $=4.862667$ Watt $\times 8$ Jam $=38.90133 \mathrm{Wh}$ 


\section{KILAT}

Vol. 8, No. 2, Oktober 2019, P-ISSN 2089-1245, E-ISSN 2655-4925

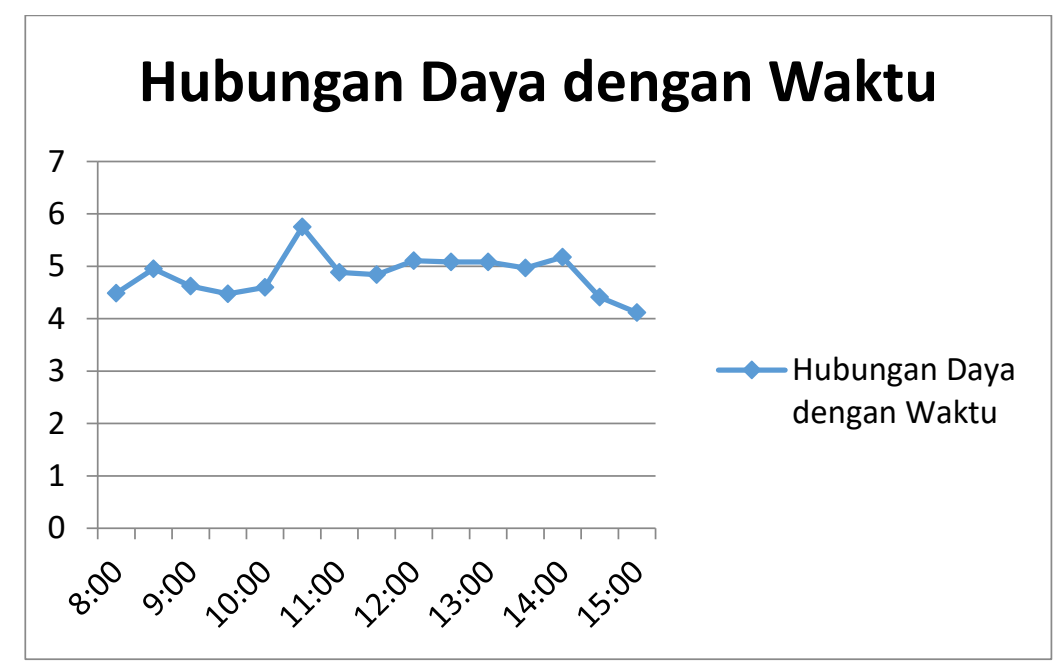

Gambar 8. Grafik modul surya posisi kemiringan panel $-5^{0}$ dari posisi awal per setengah jam dengan waktu

Berdasarkan Gambar 8 terlihat bahwa daya tertinggi didapat pada jam 10:30. Namun daya yang dihasilkan pada percobaan ini lebih efisien dari pada percobaan 5. Karena daya yang dihasilkan percobaan 6 dengan merotasikan setiap setengah jam masih lebih besar dari pada percobaan ke 5 dengan merotasikan setiap satu jam pada posisi $-5^{0}$ dari setiap jam nya. Pada penelitian kali ini, agar mendapatkan hasil yang maksimal, dilakukan dengan merotasikan modul surya. Gerak yang dilakukan sebaiknya setengah jam sekali dengan sudut kemiringan $+5^{0}$ dari posisi awal tracking agar memaksimalkan energi yang dihasilkan oleh modul surya. Poin penting dalam memaksimalkan hasil ini juga berpengaruh besar pada kapasitas modul surya.

\section{KESIMPULAN DAN SARAN}

1. Energi yang dihasilkan oleh solar tracking sistem lebih optimal dibandingkan dengan modul surya dalam keadaan diam. Perubahan posisi modul surya dilakukan sebaiknya setengah jam sekali dengan sudut kemiringan $+5^{0}$ dari posisi awal perubahan jam.

2. Pada posisi modul surya diam, daya maksimum terdapat pada jam 12.30 wib yaitu sebesar 5,129 watt.

3. Pada posisi modul surya berotasi, daya maksimum terdapat pada jam 10.30 wib yaitu sebesar 5,75 watt. Hal ini dikarenakan temperatur modul surya pada jam 12.00 wib sangatlah tinggi. Semakin tinggi temperatur pada modul surya arus yang diproduksi dari modul surya pada kenyataannya tetap, sebaliknya tegangan mengalami penurunan. Dan bersamaan dengan itu performa dari modul surya dalam produksi energi listrik berkurang.

\section{UCAPAN TERIMAKASIH}

Penulis mengucapkan terima kasih kepada LPPM STT PLN yang telah memberi dukungan yang membantu pelaksanaan penelitian dan atau penulisan artikel.

\section{DAFTAR PUSTAKA}

[1] Hajar, Ismu. (2015). "Studi Perencanaan Penambahan Daya Pada Pembangkit Listrik Tenaga Surya, Pulau Salemo". Jakarta. Teknik Elektro STT PLN. 
[2] Irwati, Rina, Zuhaidi, Hadiono, Adjar. (2011). "Pengaruh Temperatur/Suhu Terhadap Tegangan Yang Dihasilkan Panel Surya Jenis Monocrystalin (Studi Kasus : Baristand Industri Surabaya)". Surabaya. Kementrian Perindustrian.

[3] Liem Ek Bien.( 2008). "Perancangan Sistem Hibrid Pembangkit Listrik Tenaga Surya Dengan Jala-jala Listrik PLN Untuk Rumah Pekotaan”. Fakultas Teknologi Industri.

[4] Rumbayan, "Radiasi Matahari di Indonesia". Jakarta. PT.Green Energi Indotama.

[5] Santiari, Dewa Ayu Sri. (2011). "Studi Pemanfaatan PLTS Sebagai catu Daya Tambahan pada Industri Perhotelan di Nusa Lembongan Bali". Denpasar. Teknik Elektro Universitas Udayana.

[6] Siregar RR, Wardana N. Luqman.“. Sistem Monitoring Kinerja Panel Listrik Tenaga Surya Menggunakan Arduino Uno.” JETri J. Ilm. Tek. Elektro. 2017;14(2):81-100.

[7] Sukmajati, S., \& Hafidz, M. (2015). Perancangan Dan Analisis Pembangkit Listrik Tenaga Surya Kapasitas $10 \mathrm{Mw}$ On Grid Di Yogyakarta. Energi \& Kelistrikan, 7(1), 49-63. https://doi.org/10.33322/energi.v7i1.582

[8] Yogianto, A., Hajar, I., \& Azzahra, S. (2018). Pemodelan Pembangkit Listrik Fotovoltaik Yang Terhubung Ke Jaringan. KILAT, 7(2), 201-209. https://doi.org/10.33322/kilat.v7i2.363

[9] Hasanah, A., Hariyati, R., \& Qosim, M. (2019). Konsep Fotovoltaik Terintegrasi On Grid dengan Gedung STT PLN. Energi \& Kelistrikan, 11(1), $17 \quad-26$. https://doi.org/10.33322/energi.v11i1.394

[10] Jurnal, R. (2019). Rancang Bangun Pemrograman Berbasis Sistem Cerdas Untuk Pengaturan Pengisian Batere Pembangkit Listrik Tenaga Surya. Energi \& Kelistrikan, 10(1), 1-14. https://doi.org/10.33322/energi.v10i1.316

[11] Jurnal, R. (2019). Karakteristik Pemakaian Tenaga Surya Pada Modul Solar Smart Sebagai Implementasi Dari Listrik Kerakyatan. Energi \& Kelistrikan, 10(1), 15-19. https://doi.org/10.33322/energi.v10i1.317

[12] Jurnal, R. (2019). Kajian Sistem Kinerja Plts Off-Grid 1 Kwp Di STT PLN. Energi \& Kelistrikan, 10(1), 38-44. https://doi.org/10.33322/energi.v10i1.322

[13] Jurnal, R. (2018). Implementasi Logika Fuzzy Untuk Sistem Otomatisasi Pengaturan Pengisian Batere Pembangkit Listrik Tenaga Surya. Energi \& Kelistrikan, 9(2), 111-119. Https://Doi.Org/10.33322/Energi.V9i2.41

[14] Jurnal, R. (2018). Studi Penyimpanan Energi Pada Baterai PLTS. Energi \& Kelistrikan, 9(2), 120-125. https://doi.org/10.33322/energi.v9i2.48

[15] Jurnal, R. (2019). Perancangan Dan Simulasi Sistem Offgrid Pembangkit Listrik Tenaga Surya (Plts) Untuk Tower Bts 1500watt. Energi \& Kelistrikan, 8(1), 15-19. Retrieved from https://STT PLN.e-journal.id/energi/article/view/288

[16] Jurnal, R. (2018). Upaya Tertib Listrik Terhadap Instalatir Kabel Di Daerah Padat Penduduk (Study Kasus Kec. Tambora). KILAT, 7(1), 24-29. https://doi.org/10.33322/kilat.v7i1.95 